\title{
Screening of natural compounds for the control of nosema disease in honeybees (Apis mellifera)*
}

\author{
Lara MAISTREllo $^{1}$, Marco LodesANI ${ }^{2}$, Cecilia Costa ${ }^{2}$, Francesco LeONARdi ${ }^{1}$, \\ Giovanna MARANI ${ }^{1}$, Mauro CALDON ${ }^{3}$, Franco MUTINELLI $^{3}$, Anna GRANATO ${ }^{3}$ \\ ${ }^{1}$ Dipartimento di Scienze Agrarie e degli Alimenti, Università di Modena e Reggio Emilia, via G. Amendola 2, \\ Area San Lazzaro - Pad. Besta, 42100 Reggio Emilia, Italy \\ ${ }^{2}$ Consiglio per la Ricerca e la sperimentazione in Agricoltura, Unità di Ricerca di Apicoltura e Bachicoltura \\ (CRA-API, ex Istituto Nazionale di Apicoltura), via di Saliceto 80, 40128 Bologna, Italy \\ ${ }^{3}$ Istituto Zooprofilattico Sperimentale delle Venezie, viale dell'Università, 10, 35020 Legnaro (Padova), Italy
}

Received 16 July 2007 - Revised 18 January 2008 - Accepted 4 March 2008

\begin{abstract}
The potential of some natural compounds (thymol, vetiver essential oil, lysozyme, resveratrol) for the control of nosema infection in honeybees was evaluated. A first trial aimed at screening substances, in candy preparations, on the basis of their toxicity to honeybees and bees' dietary preferences. None of the tested substances showed an increased bee mortality or decreased bee preference, and were therefore considered suitable for further testing. In the second trial the effects of the natural compounds on nosema diseased honeybees were evaluated: bees were individually dosed with nosema spores and fed candies prepared with the screened substances. The results showed that bees fed with thymol and resveratrol candies had significantly lower infection rates, and bees supplied with resveratrol prepared candy also lived significantly longer. We suggest that thymol and resveratrol could be useful in alternative strategies for the control of nosema disease.
\end{abstract}

Nosema / microsporidian / honeybee / thymol / resveratrol

\section{INTRODUCTION}

Nosema disease in European honeybees (Apis mellifera L.) is caused by the microsporidian Nosema apis Zander, although recent studies have shown that the microsporidian Nosema ceranae (Fries et al., 1996), first isolated from the Asian honeybee (Apis cerana Fabricius), can infect $A$. mellifera (Higes et al., 2006; Huang et al., 2007, 2008) and may be responsible for the increase of the incidence of the disease observed in some European countries (Martín et al., 2005). Nosema apis is an obligate parasite of the gut tissue of

Corresponding author: Lara Maistrello, lara.maistrello@unimore.it

* Manuscript editor: Marla Spivak adult bees (de Graaf et al., 1994); transmission of the disease occurs via trophallaxis (Webster, 1993) and ingestion of infected comb (Bailey and Ball, 1991) and water sources (L'Arrivee, 1965), as the spores expelled in large quantities with the faeces of diseased individuals remain viable for more than a year (Fries, 1993). Many compounds have been tested for the control of nosema, but the only effective product is the antibiotic fumagillin (Moffet et al., 1969), which inhibits the development of $N$. apis in the honeybee (Katznelson and Jamieson, 1952; Liu, 1973). As the use of antibiotics for treatment of diseased beehives is forbidden in most European countries, control of the disease is carried out mainly by applying preventive measures, such as placing hives in non-damp areas, transferring bees 
onto non-contaminated equipment and fumigation of combs with acetic acid to kill $N$. apis spores. Even where treatments with fumagillin are possible there is the problem of reoccurence of the disease, as according to some authors only the vegetative forms of the parasite are killed (MacDonald, 1978; Szabo and Heikel, 1987; Wyborn and McCutcheon, 1987), while Liu (1973) suggests fumagillin is able to alter the ultrastructure of the membrane in young spores. Although there are no reports of fumagillin residues following treatment for nosema disease, it has been shown that this antibiotic is very stable in honey (Assil and Sporns, 1991). Furthermore the use of antibiotics and sulpha drugs for honeybee diseases represents a growing concern to the honey market, also due to the increasing power of residue detection of laboratory instruments. The development of new methods for the control of nosemosis is therefore much hoped for by beekeepers throughout temperate climates. To approach this issue we decided to evaluate the nosema control potential of several substances of natural origin with reported or possible inhibitory effect on the development of microsporidians: thymol, vetiver essential oil, lysozyme and resveratrol. We chose to deliver these substances to the bees in the kind of feed provided to hives during the winter (candy), traditionally the period of highest susceptibility to nosema, although in the case of $N$. ceranae a recent study (Martìn-Hernández et al., 2007) showed that high prevalence of the infection is not linked only to the winter months.

Thymol (3-hydroxy-p-cymene), a constituent of the essential oil derived from thyme and many other plant species, has been shown to suppress Nosema vespula disease in Helicoverpa armigera caterpillars and some evidence suggests that thymol may suppress nosema disease in honeybee colonies (Rice, 2001; Yucel and Dogaroglu, 2005). Thymol is known to be effective in inhibiting the growth of pathogenic bacteria and fungi, such as Salmonella typhimurium, Staphylococcus aureus (Juven et al., 1994), Aspergillus flavus (Mahmoud, 1999) and Cryptococcus neoformans (Viollon and Chaumont, 1994). In apiculture thymol is well known due its suppressive effects against the parasitic mite Varroa destructor (Chiesa, 1991) and honeybees are tolerant to its use through physical contact (Imdorf et al., 1995). Also, recent research has shown that thymol fed orally to adult bees is not toxic (Ebert et al., 2007).

Thymol's low toxicity (Lenga, 1988) and low residuality in honey (Bogdanov et al., 1998) have allowed this substance to be approved for use of varroa control in organic beekeeping, according to EU Regulation No. 834/2007 (EC, 2007).

Vetiver essential oil is distilled from the roots of Vetiveria zizanioides and contains more than 300 compounds with a dominance of sesquiterpenes (Sellier and Cazaussus, 1991). Experiments in which termites (Coptotermes formosanus) were provided with food or substrate treated with vetiver oil showed that it had a marked repellent and anti-feedant property, and a lethal effect on the symbiotic flagellates (necessary for termites to digest wood) (Maistrello et al., 2001a, b). The repellent property of vetiver oil was active also towards ants, ticks and cockroaches (Henderson et al., 2003).

Lysozyme is an enzyme with bacteriolytic activity. It is present in high quantities in albumen and other animal fluids and secretions such as mucosa, blood and milk (Barbara and Pellegrini, 1975). Lysozyme is toxic towards many Gram-positive bacteria and also appears to have anti-viral effects (Lodi, 1989).

Resveratrol (trans- 3,5,4'-trihydroxystilbene) is a phytoalexin produced by certain plants in response to infections caused by phytopathogenic microorganisms, and is known for its anti-cancer and anti-inflammatory effects (Fremont, 2000). Recent studies have showed that resveratrol can inhibit the development of the microsporidian Encephalitazoon cunicoli in in vitro experiments (Leiro et al., 2004).

The aim of this study was to evaluate the nosema control potential of thymol, vetiver oil, lysozyme and resveratrol, firstly by evaluating bee susceptibility and diet preference, secondly by artificially infecting bees with the parasite and providing them with feed prepared with the selected active ingredients. 
Table I. Natural products used in the experiment.

\begin{tabular}{cccc}
\hline Acronym & A.I. & $\begin{array}{c}\text { Concentration } \\
(\mathrm{mg} / \mathrm{g})\end{array}$ & Product name and owner company \\
\hline T1 & thymol & 0.12 & Thymol minimum 99.5\%, Sigma \\
T2 & thymol & 2.5 & Thymol minimum 99.5\%, Sigma \\
L1 & lysozyme & 0.5 & Lisozima 500, SPA Milano \\
L2 & $\begin{array}{c}\text { lysozyme } \\
\text { vetiver }\end{array}$ & 0.06 & Lisozima 500, SPA Milano \\
V1 & 1.2 & Vetivert, Prosperità Srl, Castel S. Pietro T. \\
essential oil & (BO) \\
V2 & $\begin{array}{c}\text { vetiver } \\
\text { essential oil }\end{array}$ & 0.6 & Vetivert, Prosperità Srl, Castel S. Pietro T. \\
R1 & resveratrol & 0.01 & (BO) \\
R2 & resveratrol & 0.001 & Resveratrol approx. 99\% GC, Sigma \\
\hline
\end{tabular}

\section{MATERIALS AND METHODS}

\subsection{Bee susceptibility and diet preference experiment}

Apis mellifera ligustica Spinola workers were obtained from a colony of the CRA-API apiary in Reggio Emilia, from which representative samples of bees were previously analyzed and the absence of nosema spores was verified. Combs with capped cells close to emergence were brought into the laboratory and kept in a thermostat $\left(34^{\circ} \mathrm{C}\right)$ for 6 hours. Newly emerged bees were then manually collected from the combs and placed in small wooden, glasssided cages measuring $10 \times 10 \times 20 \mathrm{~cm}$, approximately 20 bees to each cage, and kept at $33{ }^{\circ} \mathrm{C}$, $70 \% \mathrm{RH}$, in the dark. A sample of newly emerged bees was further analysed to confirm the absence of nosema spores.

Bee candy was prepared by mixing powdered sugar $(85 \%)$, sterilised honey $(10 \%)$ and water $(5 \%)$. The natural compounds were added to the honey during preparation of the candy and ethanol was used to aid their solubility; a control candy (CE) containing ethanol $(3.2 \mu \mathrm{L} / \mathrm{g})$ was set up as well as control candy without ethanol (C).

The concentrations of the natural compounds in the candy were chosen on the basis of preliminary tests and previous research (Albo et al., 2003; Maistrello et al., 2003) and are shown in Table I. The candy, contained in a $3 \mathrm{~cm}$ diameter Petri dish $(9 \mathrm{~g})$, was positioned upside-down on a $1 \mathrm{~cm}$ diameter hole on top of the cage. A gravity feeder containing water was also fitted on the cages. A minimum number of two cages per product and concentration were set up yielding a total of 30 test cages.

On the 4th, 7th and 11th day from the beginning of the experiment, the candy dishes were weighed to estimate the feed intake and dead bees in each cage were counted and removed.

Bee susceptibility toward the experimental substances was evaluated by means of one-way analysis of variance (ANOVA), considering the percentage of dead bees on the last day of the experiment, transformed in arcsin of the square root. Results are graphically reported as untransformed data.

Average daily feed intake of bees fed with the differently treated candies were compared by ANOVA, to verify the bees' dietary preference towards the experimental substances.

\subsection{Infection experiment}

Bees infected with nosema were obtained from an apiary where the disease is endemic, in the North-west of Italy. Bee samples were collected and analysed to verify whether the bees were infected with $N$. apis or $N$. ceranae, according to the method described by Higes et al. (2006).

To obtain the spore suspension, the infected bees were crushed in saline solution, filtered through nylon mesh and further purified by two rounds of centrifugation and re-suspension in saline solution. The concentration of spores was then determined by haemacytometer count (Cantwell and Shimanuki, 1970) using phase-contrast light microscopy. After another centrifugation the spores were re-suspended in $50 \% \mathrm{w} / \mathrm{v}$ sucrose solution, in an amount necessary to yield a final concentration of about 18000 spores per $\mu \mathrm{L}$, which is included in the range of concentrations $\left(10^{4}\right.$ $10^{5}$ spores $/ \mu \mathrm{L}$ ) used by other authors for similar experiments (Forsgren and Fries, 2003; Malone and Giacon, 1996; Malone et al., 2001; Webster et al., 


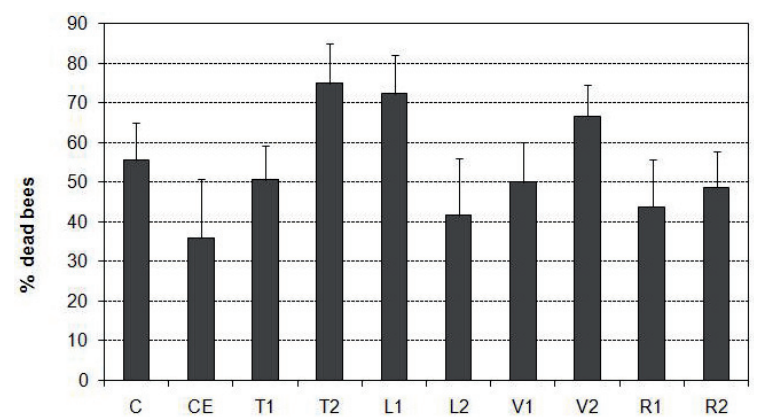

Figure 1. Average $(+\mathrm{SE})$ percentage of dead bees per differently fed group $(\mathrm{C}=\mathrm{Control}, \mathrm{CE}=\mathrm{Control}$ Ethanol, T1 = Thymol $0.12 \mathrm{mg} / \mathrm{g}$, T2 = Thymol $0.06 \mathrm{mg} / \mathrm{g}, \mathrm{L} 1=$ Lysozyme $2.5 \mathrm{mg} / \mathrm{g}, \mathrm{L} 2=$ Lysozyme $0.5 \mathrm{mg} / \mathrm{g}, \mathrm{V} 1$ = Vetiver oil $1.2 \mathrm{mg} / \mathrm{g}, \mathrm{V} 2$ = Vetiver oil $0.6 \mathrm{mg} / \mathrm{g}, \mathrm{R} 1$ = Resveratrol $0.01 \mathrm{mg} / \mathrm{g}, \mathrm{R} 2=$ Resveratrol $0.001 \mathrm{mg} / \mathrm{g}$ ).

2004). The spore suspension was prepared immediately before inoculating the bees. An aliquot of the spore suspension was used for the DNA sequencing.

Newly emerged, nosema-free worker honeybees were manually collected as described in the previous experiment (Sect. 2.1) and kept in wooden cages for 24 hours. The bees had access to gravity feeders containing sucrose syrup $50 \%(\mathrm{w} / \mathrm{v})$ which were removed 2 hours before individually force-feeding the bees with $1 \mu \mathrm{L}$ of the inoculated sucrose syrup suspension, according to the method described by Malone and Gatehouse (1998). Immediately after inoculation, the bees were placed in the cages, approximately 30 bees each, and kept at $33{ }^{\circ} \mathrm{C}, 70 \% \mathrm{RH}$, in the dark.

Candies were prepared as described above, containing the highest concentration of each substance: thymol $0.12 \mathrm{mg} / \mathrm{g}$ (T1); lysozyme $2.5 \mathrm{mg} / \mathrm{g}$ (L1); vetiver $1.2 \mathrm{mg} / \mathrm{g}(\mathrm{V} 1)$, resveratrol $0.01 \mathrm{mg} / \mathrm{g}$ (R1). As no differences in intake or bee susceptibility had been observed between the two kinds of control, in this experiment we used the control candy containing ethanol (CE).

Each treatment was replicated 4 times thus yielding a total of 20 cages ( 5 treatments $\times 4$ replicates).

Starting from the second day after inoculation the number of dead bees in each cage was recorded daily. To monitor the development of the infection two live bees were removed from each cage at 8 , 13, 19 and 25 days after inoculation (monitoring time points). The ventriculus and rectum of the bees were removed and kept with $1 \mathrm{~mL}$ saline solution at $-20{ }^{\circ} \mathrm{C}$ until the spore count was performed.

For the calculation of survival times the live bees collected for monitoring the infection at 8 , 13, 19 and 25 days were considered as censored data. A multiple sample test was performed to verify that there were no statistical differences among the life tables of the replications of each differently fed group (CE, T, L, V, R). Life tables for each group were then calculated (pooling the data for each group) and median survival times were obtained (the survival time at which the cumulative survival function is equal to 0.5 ). A multiple sample test was performed to detect significant differences among the life tables of the different feeding groups, followed by paired comparisons carried out with log rank test.

Spore loads of the differently fed bees removed at the 4 monitoring time points were compared using Kruskal-Wallis nonparametric test and paired comparisons were performed by means of MannWhitney $\mathrm{U}$ test. A significance level of $P=0.05$ was used to define statistical differences.

All analyses were carried out using StatisticaStatSoft v. 7.1.

\section{RESULTS}

\subsection{Bee susceptibility and diet preference experiment}

Average mortality of the caged bees fed with the experimental candies after 11 days was $54 \%$ and no significant differences were detected among the groups $(F=1.34$, d.f. $=9$, $P=0.278$ ) (Fig. 1).

The daily bee intake of candy was $49 \mathrm{mg}$ on average and no significant differences were detected in the statistical comparison $(F=1.73$, d.f. $=9, P=0.148$ ) (Fig. 2). 


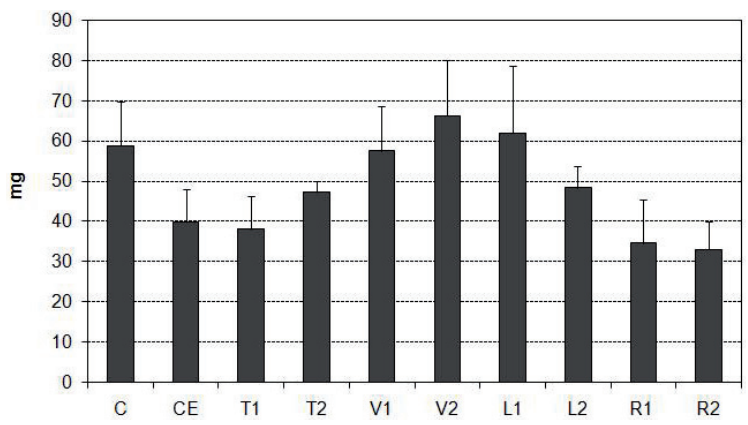

Figure 2. Average $(+\mathrm{SE})$ daily candy intake $(\mathrm{mg})$ per bee $(\mathrm{C}=\mathrm{Control}, \mathrm{CE}=\mathrm{Control}$ Ethanol, $\mathrm{T} 1=$ Thymol $0.12 \mathrm{mg} / \mathrm{g}, \mathrm{T} 2=$ Thymol $0.06 \mathrm{mg} / \mathrm{g}, \mathrm{L} 1=$ Lysozyme $2.5 \mathrm{mg} / \mathrm{g}, \mathrm{L} 2=$ Lysozyme $0.5 \mathrm{mg} / \mathrm{g}, \mathrm{V} 1=$ Vetiver oil $1.2 \mathrm{mg} / \mathrm{g}, \mathrm{V} 2$ = Vetiver oil $0.6 \mathrm{mg} / \mathrm{g}, \mathrm{R} 1=$ Resveratrol $0.01 \mathrm{mg} / \mathrm{g}, \mathrm{R} 2=$ Resveratrol $0.001 \mathrm{mg} / \mathrm{g}$ ).

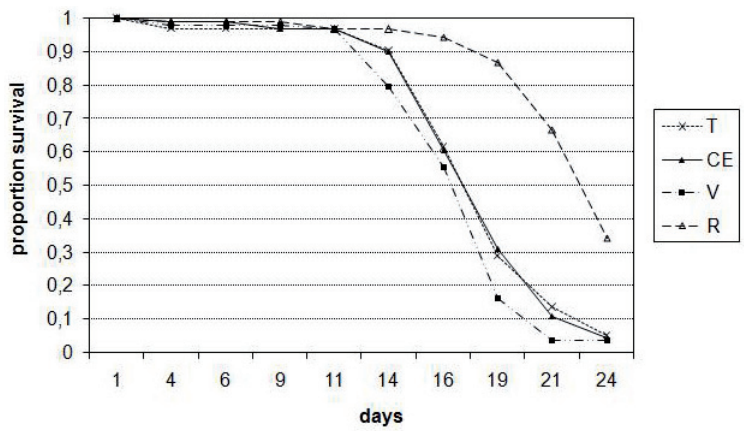

Figure 3. Survival curves of the differently fed groups $(\mathrm{CE}=$ Control Ethanol, $\mathrm{T}=$ Thymol $0.12 \mathrm{~g} / \mathrm{kg}$, $\mathrm{V}=$ Vetiver oil $1.2 \mathrm{~g} / \mathrm{kg}, \mathrm{R}=$ Resveratrol $0.001 \mathrm{~g} / \mathrm{kg}$ ). Recordings were made on the 8th, 13th, 19th and 25th day post infection.

\subsection{Infection experiment}

Molecular diagnosis of all the analysed samples, revealed that spores used in the bioassay belonged to the $N$. ceranae species.

The comparisons among life tables within each feeding group were not significant for control $\left(\chi^{2}=1.18\right.$, d.f. $\left.=3, P=0.76\right)$, vetiver oil $\left(\chi^{2}=5.82\right.$, d.f. $\left.=3, P=0.12\right)$, resveratrol $\left(\chi^{2}=4.72\right.$, d.f. $\left.=3, P=0.19\right)$, and thymol $\left(\chi^{2}=2.45\right.$, d.f. $\left.=3, P=0.48\right)$ but highly significant for lysozyme $\left(\chi^{2}=17.60\right.$, d.f. $=3$, $P=0.0005)$; the group treated with this substance was therefore not considered in the following statistical analyses. The multiple sample test indicates significant differences $\left(\chi^{2}=\right.$ 83.14 , d.f. $=3, P<0.0001)$ among the lifetables of the differently fed groups. Log-rank tests showed that the survival curve of bees fed with resveratrol was significantly different from the other curves and that resveratrol-fed bees had a significantly higher median survival time compared to all the other groups (Fig. 3, Tab. II).

Development of $N$. ceranae infection in bees belonging to the different feeding groups is shown in Table III. The greatest increase in the infection rate between the last two time points was registered in the control group, with a 3.4-fold mean increase which also had the highest absolute infection level by the end of the experiment (230 mil spores/bee). Bees provided with lysozyme candy showed a high increase in spore load from the $13 \mathrm{~d}$ time point, and all bees had died by the $25 \mathrm{~d}$ time point. Bees fed with the vetiver candy had levels of infection intermediate between the control and the differently fed groups, displaying a rapid increase in the infection rates especially 
Table II. Results of log-rank tests performed to compare survival times from different experimental groups. Numbers in brackets below each group name represent median survival times, in days, obtained from the related survival function analysis $(\mathrm{CE}=$ Control Ethanol, $\mathrm{T}=$ Thymol $0.12 \mathrm{mg} / \mathrm{g}, \mathrm{V}=$ Vetiver oil $1.2 \mathrm{mg} / \mathrm{g}$, $\mathrm{R}=$ Resveratrol $0.001 \mathrm{mg} / \mathrm{g}$ ). Bold characters identify significant differences.

\begin{tabular}{ccccc}
\hline & $\mathrm{CE}$ & $\mathrm{T}$ & $\mathrm{V}$ & $\mathrm{R}$ \\
& $(18.00)$ & $(18.00)$ & $(15.00)$ & $(21.50)$ \\
\hline $\mathrm{CE}$ & - & $Z=0.11 ; P=0.92$ & $Z=1.85 ; P=0.06$ & $\boldsymbol{Z}=\mathbf{6 . 7 3} \boldsymbol{P}<\mathbf{0 . 0 0 0 1}$ \\
$\mathrm{T}$ & - & - & $Z=1.88 ; P=0.06$ & $\boldsymbol{Z}=\mathbf{6 . 5 7} \boldsymbol{P}<\mathbf{0 . 0 0 0 1}$ \\
$\mathrm{V}$ & - & - & - & $\boldsymbol{Z}=\mathbf{7 . 7 2} \boldsymbol{P}<\mathbf{0 . 0 0 0 1}$ \\
\hline
\end{tabular}

Table III. Mean number of spores (millions per bee) \pm SE in the bees collected at different time points (d) in the cages of the different feeding groups $(\mathrm{CE}=$ Control Ethanol, $\mathrm{T}=$ Thymol $0.12 \mathrm{mg} / \mathrm{g}, \mathrm{L}=$ Lysozyme $2.5 \mathrm{mg} / \mathrm{g}, \mathrm{V}=$ Vetiver oil $1.2 \mathrm{mg} / \mathrm{g}, \mathrm{R}=$ Resveratrol $0.001 \mathrm{mg} / \mathrm{g})$. Pooled data from all repetitions $(\mathrm{N}=8)$. In the column " $25 \mathrm{~d}$ ", means followed by the same letter are not significantly different after Mann-Whitney U test. N.d. = not determined.

\begin{tabular}{lclcc}
\hline & $8 \mathrm{~d}$ & \multicolumn{1}{c}{$13 \mathrm{~d}$} & $19 \mathrm{~d}$ & $25 \mathrm{~d}$ \\
\hline $\mathrm{CE}$ & $2.6 \pm 0.89$ & $38.5 \pm 6.33$ & $67.4 \pm 19.77$ & $230 \pm 10 \mathrm{c}$ \\
$\mathrm{T}$ & $2.46 \pm 0.31$ & $31.7 \pm 13.84$ & $29.8 \pm 10.44$ & $20.2 \pm 10.44 \mathrm{a}$ \\
$\mathrm{L}$ & $1.87 \pm 0.63$ & $63.6 \pm 10.87$ & $76.4 \pm 9.15$ & N.d. \\
$\mathrm{V}$ & $1.37 \pm 0.44$ & $36.4 \pm 6.3$ & $58.5 \pm 16.50$ & $144.5 \pm 40.50 \mathrm{bc}$ \\
$\mathrm{R}$ & $3.3 \pm 1.06$ & $28.9 \pm 8.08$ & $65.97 \pm 8.49$ & $54 \pm 8.68 \mathrm{~b}$ \\
\hline
\end{tabular}

between $19 \mathrm{~d}$ (58.5 million spores/bee) and $25 \mathrm{~d}$ (144.5 mil spores/bee); this 2.5 -fold increase was lower only than the increase in the control group $(\times 3.4)$. In bees fed with resveratrol and thymol treated candy on the other hand, a decrease in the infection levels was registered at the last time point $(25 \mathrm{~d})$ compared to the previous ones. In resveratrol fed bees the infection level at $25 \mathrm{~d}$ (54 million spores/bee) was, on average, lower than infection levels at the previous time point $(65.97$ mil spores/bee at $19 \mathrm{~d}$ ) and considerably lower than infection levels in control bees (230 million spores/bee). Bees fed with thymol candy showed a progressive decrease in infection levels at $19 \mathrm{~d}$ (6\% less compared to $13 \mathrm{~d})$ and at $25 \mathrm{~d}(68 \%$ less compared to $19 \mathrm{~d})$ and the lowest mean infection level at the end of the experiment (20.2 million spores/bee), corresponding to $8.8 \%$ of infection level in control bees.

Comparisons among different feeding groups at each of the 4 time points (Tab. III), highlighted significant differences only at 25d $\left(\chi^{2}=8.34 ; P=0.039\right)$. The paired comparisons detected that bees fed with thymol candy had lower spore loads compared to all the other groups (thymol-control: $\mathrm{U}=0.0 ; P=0.021$; thymol-resveratrol:
$\mathrm{U}=0.0 ; P=0.020$; thymol-vetiver: $\mathrm{U}=0.0$; $P=0.034)$. Bees fed with resveratrol candy had significantly lower spore loads than control bees $(\mathrm{U}=0.0 ; P=0.020)$, whereas bees fed with vetiver candy had spore levels similar to control bees, with a progressive increase in spore production, especially between $19 \mathrm{~d}$ and $25 \mathrm{~d}$.

\section{DISCUSSION}

The results showed that vetiver oil, thymol, resveratrol and lysozyme, at the used concentrations, caused no toxic effects on the adult bees, nor anti-feedant properties, as candy intake was similar throughout the experimental groups. All the compounds were therefore considered suitable for treating bees in experiments against nosema disease, at the highest of the tested concentrations.

In the infection experiment very high spore loads were observed at the last time point, especially in the control group. This is in agreement with data from Lotmar (1943), who observed that if there is no flight possibility and spores are allowed to accumulate in the rectum, more than 200 million spores can be 
found in a single bee. It has been observed also that when bees are very infected and whole abdomens are considered, it is possible to find 180-500 million spores per bee (Lotmar, 1940; Gontarski and Wagner, 1954; Borchert, 1966; Furgala and Mussen, 1990; Hornitzky, 2005). Although we cannot exclude differences in spore counts due to defecation of monitored bees, there was no evidence to suggest that defecation was influenced by the kind of treatment.

Concerning the comparison among substances, thymol and resveratrol were shown to have significant effects on reducing spore loads, while vetiver oil and lysozyme were ineffective in this sense.

It appears that thymol inhibits the development of the parasite, as the infestation level in bees fed with thymol candy was lower at the end of the experiment ( $25 \mathrm{~d})$ than at intermediate time points ( $13 \mathrm{~d}$ and $19 \mathrm{~d}$ ). Furthermore, at all sampling dates, spore concentrations were lowest in the thymol fed bees compared to differently fed bees (at the end of the test thymol fed bees contained 11.5 times less nosema spores than control bees). These findings may support the hypothesis by Rice (2001) that thymol enters the nosema spore, disrupts the plasma membrane and prevents germination. Further studies are nevertheless necessary to understand the mechanisms by which thymol affects the biological cycle of the parasite.

In bees fed with resveratrol candy the reduction of spore load corresponded to increase in lifespan. A significant anti-microsporidian activity of resveratrol has also been observed by Leiro et al. (2004). Furthermore, it has been shown that resveratrol increases the lifespan of invertebrates such as Caenorhabditis elegans and Drosophila and of small vertebrates (Valenzano et al., 2006). The increased lifespan in resveratrol treated bees may therefore have been independent from the effect on the development of nosema infection but due to the specific anti-oxidant properties of resveratrol. Further research is needed to clarify these aspects.

Vetiver oil, which reduced the number of symbiotic microorganisms in termites, was however ineffective in reducing nosema infection in honeybees.
Lysozyme, although known for its antibacterial activity, was not at all able to reduce the development of this microsporidians.

The results of our experiments show that thymol and resveratrol undoubtedly have potential in the development of alternative strategies for the control of nosema disease. These substances could be used for treating colonies without risk of damaging the image of honey as a natural product. Although previous work showed that high concentrations of thyme essential oil can have toxic effects on honeybees (in accordance with its classification as a moderately toxic product) and may not be palatable, different doses of thymol and resveratrol could be tested in order to find the highest effective tolerable concentrations at the colony level. In future experiments we will also evaluate different feeding modes, such as sugar syrup, which is absorbed by the bees in greater quantities than candy and is commonly used by beekeepers to feed the colonies in spring and autumn.

\section{ACKNOWLEDGEMENTS}

We wish to thank Angelo Barberis for providing nosema diseased bees, Simone Franceschetti for the work in the bee yard and Eleonora Bergomi for assistance in the laboratory.

Sélection de composés naturels pour lutter contre la nosémose des abeilles domestiques (Apis mellifera).

Nosema / microsporidie / abeille / thymol / resveratrol

Zusammenfassung - Prüfung von Naturstoffen zur Bekämpfung der Nosemose bei Honigbienen (Apis mellifera). Effektive Wirkstoffe zur Bekämpfung der Nosemose werden europaweit dringend benötigt, da es keine zugelassenen Präparate gibt und sich die Krankheit zunehmend ausbreitet. Die Nosemose ist ein weltweites Problem für die Bienenhaltung. Die Krankheit wird durch die Mikrosporidien Nosema apis Zander und Nosema ceranae Fries verursacht, wobei sie als obligate Parasiten des Darmepithels die adulten Bienen schädigen. Die Ansteckung erfolgt über Sporen, die in großer Menge im Kot von kranken Bienen nachweisbar sind. Sie sind länger als ein Jahr in Waben und Wasser infektiös und können zusätzlich über 
Trophallaxis verbreitet werden. Das einzige bisher wirksame Produkt zur Bekämpfung der Nosemose ist das Antibiotikum Fumagillin, das aber in vielen Ländern verboten ist. Das Ziel dieser Untersuchung war es, verschiedene Naturstoffe, die ohne das Risiko einer Rückstandsbildung in Bienenprodukten eingesetzt werden können, hinsichtlich ihrer Wirksamkeit gegen die Nosemose zu testen. Da von Thymol, Vetiveröl, Lysozym und Resveratrol bereits Berichte über inhibitorische Wirkungen auf Mikrosporidien vorlagen, wurden diese für die Tests ausgewählt und den Bienen über das Futter appliziert. In einem ersten Versuch wurden die Substanzen in zwei unterschiedlichen Konzentrationen hinsichtlich der toxischen Effekte und ihrer Akzeptanz als Futterzusatz geprüft. Jeweils 20 Bienen wurden in kleinen Holzkäfigen bei $33{ }^{\circ} \mathrm{C}$ und $70 \% \mathrm{RF}$ im Dunkeln gehalten und die Futterabnahme sowie die Anzahl toter Bienen bis zum elften Tag erfasst. Dabei wurden keine Unterschiede zwischen den unterschiedlich gefütterten Versuchsgruppen festgestellt (Abb. 1, 2). In einem zweiten Versuch wurden Nosema-freie Bienen einzeln mit $1 \mu \mathrm{L}$ einer sporenhaltigen Zuckerlösung mit jeweils $18000 \mathrm{~N}$. ceranae Sporen gefüttert. 30 Bienen pro Käfig wurden mit Zuckerteig, der jeweils die höchste getestete Konzentration der o. a. Substanzen enthielt, gefüttert. Aus jedem Käfig wurden 8, 13, 19 und 25 Tage nach Versuchsbeginn je 2 Bienen entnommen und deren Sporenbelastung bestimmt, um die Entwicklung der Nosemainfektion zu verfolgen. Zusätzlich wurde täglich die Anzahl toter Bienen registriert, um die Überlebensraten zu berechnen. Die mit Resveratrol gefütterten Bienen wiesen eine signifikant höhere mittlere Überlebenszeit auf (Abb. 3, Tab. II). Bei Bienen, die mit Resveratrol und Thymol gefüttert wurden, kam es am letzten Untersuchungszeitpunkt (Tag 25) zu einer Reduzierung des NosemaInfektionsgrades, während in den anderen Gruppen die Anzahl an Sporen zunahm (Tab. III). Bei den mit Thymol gefütterten Bienen war die Sporenkonzentration zu allen Untersuchungszeitpunkten am geringsten. Es scheint, dass Thymol und Resveratrol geeignete Substanzen sind, um die Entwicklung des Parasiten zu hemmen. Thymol wird bereits als wirksames Akarizid gegen Varroa-Milben in der Imkerpraxis eingesetzt und Resveratrol ist bekannt für seine spezifischen antioxidativen Eigenschaften, die in anderen Versuchen bereits zur Verlängerung der Lebensdauer kleiner Invertebraten geführt haben.

\section{Nosema / Mikrosporidien / Honigbienen / Thy- mol / Resveratrol}

\section{REFERENCES}

Albo G.N., Henning C., Ringuelet J., Reynaldi F.J., De Giusti M.R., Alippi A.M. (2003) Evaluation of some essential oils for the control and prevention of American Foulbrood disease in honey bees, Apidologie 34, 417-427.

Assil H.I., Sporns P. (1991) ELISA and HPLC methods for analysis of fumagillin and its decomposition products in honey, J. Agric. Food Chem. 39, 22062213.

Bailey L., Ball B.V. (1991) Honey bee pathology, Academic Press, London.

Barbara L., Pellegrini R. (1975) Il lisozima di Fleming. Significato biologico e applicazioni terapeutiche, Edizioni Minerva Medica, Torino.

Bogdanov S., Kilchenmann V., Imdorf A., Fluri P. (1998) Residues in honey after application of thymol against varroa using the franko thymol frame, Am. Bee J. 133, 610-611.

Borchert A. (1966) Krankheiten und Schädlinge der Honigbiene, S. Hirzel Verlag, Leipzig.

Cantwell G.E., Shimanuki H. (1970) The use of heat to control nosema and increase production for the commercial beekeeper, Am. Bee J. 110, 263.

Chiesa F. (1991) Effective control of varroatosis using powdered thymol, Apidologie 22, 135-145.

de Graaf D.C., Raes H., Sabbe G., De Rycke P.H., Jacobs F.J. (1994) Early development of Nosema apis (Microspora: Nosematidae) in the midgut epithelium of the honeybee (Apis mellifera), J. Invertebr. Pathol. 63, 74-81.

Ebert T.A., Kevan P.G., Bishop B.L., Kevan S.D., Downer R.A. (2007) Oral toxicity of essential oils and organic acids fed to honey bees (Apis mellifera), J. Apic. Res. 46, 220-224.

EC (2007) Council Regulation No. 834/2007 of 28 June 2007 on organic production and labelling of organic products and repealing Regulation (EEC) No. 2092/91, Off. J. Eur. Union L189, 20.07.2007, $1-23$.

Forsgren E., Fries I. (2003) Acidic food and nosema (Nosema apis) disease, in: Proc. XXXVIIIth Apimondia Int. Apic. Congr Ljubljana, Slovenia, August 24-29, 2003, pp. 488-489.

Fremont L. (2000) Biological effects of resveratrol, Life Sci. 66, 663-673.

Fries I. (1993) Nosema apis - A parasite in the honey bee colony, Bee World 74, 5-19.

Fries I., Feng F., Silva A. da, Slemenda S.B., Pieniazek N.J. (1996) Nosema ceranae n. sp. (Microspora, Nosematidae), morphological and molecular characterization of a microsporidian parasite of The Asian honey bee Apis cerana (Hymenoptera, Apidae), Eur. J. Protistol. 32, 356-365.

Furgala B., Mussen E.C. (1990) Protozoa, in: Morse R.A., Nowogrodzki R. (Eds.), Honey bee pests, predators, and diseases, 2nd ed, Comstock, Ithaca, NY, pp. 49-63.

Gontarski G., Wagner O. (1954) Quantitative Versuche zur chemotherapeutischen Bekämpfung 
von Nosema apis Zander bei der Honigbiene, Arzneim. Forsch. 4, 161-168.

Henderson G., Heumann D.O., Laine R.A., Maistrello L., Zhu B.C.R., Chen F. (2003) Extracts of vetiver oil as a repellent and toxicant to ants, ticks, and cockroaches, US-2003-0073748-A1, U.S. Patent and Trademark Office.

Higes M., Martín R., Meana A. (2006) Nosema ceranae, a new microsporidian parasite in honeybees in Europe, J. Invertebr. Pathol. 92, 93-95.

Hornitzky M. (2005) Nosema disease. Literature review and survey of beekeepers. RIRDC Publication No. 05/055, Australian Government, Rural Industries Research and Development Corporation, http://www.rirdc.gov.au/reports/HBE/05-055.pdf.

Huang W.F., Bocquet M., Lee K.C., Sung I.H., Jiang J.H., Chen Y.W., Wang C.H. (2008) The comparison of rDNA spacer regions of Nosema ceranae isolates from different hosts and locations, J. Invertebr. Pathol. 97, 9-13.

Huang W.F., Jiang J.H., Chen Y.W., Wang C.H. (2007) A Nosema ceranae isolate form the honeybee Apis mellifera, Apidologie 38, 30-37.

Imdorf A., Kilchenmann V., Bogdanov S., Bachofen B., Beretta C. (1995) Toxic effects of thymol, camphor, menthol and eucalyptol on Varroa jacobsoni Oud and Apis mellifera L. in a laboratory test, Apidologie. 26, 27-31.

Juven B.J., Kanner J., Schved F., Weisslowicz H. (1994) Factors that interact with the antibacterial action of thyme essential oil and its active constituents, J. Appl. Bacteriol. 76, 626-631.

Katznelson H., Jamieson H. (1952) Control of nosema disease with fumagillin, Science 115, 70-71.

L'Arrivee J.C.M. (1965) Sources of nosema infection, Am. Bee J. 105, 246-248.

Leiro J., Cano E., Ubeira F.M., Orallo F., Sanmartìn M.L. (2004) In vitro effects of resveratrol on the viability and infectivity of the Microsporidian Encephalitozoon cuniculi, Antimicrob. Agents Ch. 48, 2497-2501.

Lenga R.E. (1988) The Sigma-Aldrich library of chemical safety data, Sigma-Aldrich Corporation 35 .

Liu T.P. (1973) Effects of Fumidil B on the spore of Nosema apis and on lipids of the host cell as revealed by freeze-etching, J. Invertebr. Pathol. 22, 364-368.

Lodi R. (1989) Il lisozima: situazioni e prospettive, Il latte $14,832-833$.

Lotmar R. (1940) Beiträge zur Pathologie des Bienendarmes. C. Über den Infektionsverlauf und die Vermehrung des Parasiten Nosema apis (Quantitative Untersuchungen), Landwirtsch. Jb. Schweiz. 54
Lotmar R. (1943) Über den Einfluß der Temperatur auf den Parasiten Nosema apis, Beih. Schweiz. Bienen-Zeitung 6, 261-284.

MacDonald D.N. (1978) Diseases of the honeybee, Apis mellifera (Hymenoptera: Apidae) in British Colombia, with special emphasis on nosema disease, Nosema apis (Sporozoa: Nosematidae), in the lower Fraser Valley, 13. Simon Fraser University, Canada.

Mahmoud A.L.E. (1999) Inhibition of growth and aflatoxin biosynthesis of Aspergillus flavus by extracts of some Egyptian plants, L. Appl. Microbiol 29, 334-336.

Maistrello L., Henderson G., Laine R.A. (2001a) Effects of nootkatone and a borate compound on Formosan subterranean termite (Isoptera: Rhinotermitidae) and its symbiont protozoa, J. Entomol. Sci. 36, 229-236.

Maistrello L., Henderson G., Laine R.A. (2001b) Efficacy of vetiver oil and nootkatone as soil barriers against Formosan subterranean termite (Isoptera: Rhinotermitidae), J. Econ. Entomol. 94, 1532-1537.

Maistrello L., Henderson G., Laine R.A. (2003) Comparative effects of vetiver oil, nootkatone and disodium octaborate tetrahydrate on Coptotermes formosanus and its symbiotic fauna, Pest. Manage. Sci. 59, 58-68.

Malone L.A., Gatehouse H.S. (1998) Effects of Nosema apis infection on honey bee (Apis mellifera) digestive proteolytic enzyme activity, J. Invertebr. Pathol. 71, 169-174.

Malone L.A., Gatehouse H.S., Tregidga E.L. (2001) Effects of time, temperature, and honey on Nosema apis (Microsporidia: Nosematidae), a parasite of the honeybee, Apis mellifera (Hymenoptera: Apidae), J. Invertebr. Pathol. 77, 258-268.

Malone L.A., Giacon H.A. (1996) Effects of Nosema apis Zander on inbred New Zealand honey bees (Apis mellifera ligustica L), Apidologie 27, 479486.

Martín R., Meana A., Higes M. (2005) Increase of nosemosis prevalence in Spain, Acta Parasitol. Portug. 12, 50.

Martìn-Hernández R., Meana A., Prieto L., Martìnez Salvador A., Garrido-Bailón E., Higes M. (2007) Outcome of colonization of Apis mellifera by Nosema ceranae, Appl. Environ. Microbiol. 73, 6331-6338.

Moffet J.O., Lackett J.J., Hitchcock J.D. (1969) Compounds tested for control of nosema in honey bees, J. Econ. Entomol. 62, 886-889.

Rice R.N. (2001) Nosema disease in honeybees. Genetic variation and control. Report n. 01/46, Australian Government, Rural Industries Research and Development Corporation. 
Sellier N., Cazaussus A. (1991) Structure determination of sesquiterpenes in chinese vetiver oil by gas chromatography -tandem mass spectrometry, J. Chromatogr. 557, 451-458.

Szabo T.I., Heikel D.T. (1987) Effect of dry fumagillin feeding on spring Nosema spore counts in overwintered colonies, Am. Bee J. 127, 210-211.

Valenzano D.R., Terzibasi E., Genade T., Cattaneo A., Domenici L., Cellerino A. (2006) Resveratrol prolongs lifespan and retards the onset of age-related markers in a short-lived vertebrate, Curr. Biol. 16, 296-300.

Viollon C., Chaumont J.P. (1994) Antifungal properties of essential oils e their main components upon Cryptococcus neoformans, Mycopathologia 123, 151-153.
Webster T.C. (1993) Nosema apis spore transmission among honey bees, Am. Bee J. 133, 869-870.

Webster T.C., Pomper K.W., Hunt G., Thacker E.M., Jones S.C. (2004) Nosema apis infection in worker and queen Apis mellifera, Apidologie 35, 49-54.

Wyborn M.H., McCutcheon D.M. (1987) A comparison of dry and wet fumagillin treatments for spring nosema disease suppression of overwintered colonies, Am. Bee J. 127, 207-209.

Yucel B., Dogaroglu M. (2005) The impact of Nosema apis $\mathrm{Z}$. infestation of honey bee (Apis mellifera $\mathrm{L}$.) colonies after using different treatment methods and their effects on the population levels of workers and honey production on consecutive years, Pak. J. Biol. Sci. 8, 1142-1145. 